\title{
New Combinations in Chinese Cotoneaster (Rosaceae)
}

\author{
Lu Lingti \\ Laboratory of Systematic and Evolutionary Biology, Institute of Botany, Chinese Academy of \\ Sciences, 20 Nanxincun, Xiangshan, Beijing 100093, People's Republic of China \\ Anthony R. Brach \\ Missouri Botanical Garden, \% Harvard University Herbaria, 22 Divinity Avenue, \\ Cambridge, Massachusetts 02138-2094, U.S.A. brach@oeb.harvard.edu
}

Abstract. During preparation of the account of Cotoneaster Medikus for the Flora of China, volume 9, it was found that some taxa required the following new combinations, namely Cotoneaster glaucophyllus Franchet var. serotinus (Hutchinson) L. T. Lu \& A. R. Brach, C. bullatus Bois var. floribundus (Stapf) L. T. Lu \& A. R. Brach, and C. gracilis Rehder \& E. H. Wilson var. difficilis (G. Klotz) L. T. Lu.

Key words: China, Cotoneaster, Maloideae, Rosaceae.

In the broad sense, the genus Cotoneaster Medikus consists of about 90 species and is widely distributed in temperate regions of northern Africa, continental Asia, Europe, and North America (mainly in Mexico). It is most abundant in southwestern China, with about 58 species recorded from that country which have been variously placed into about seven (to more than 20) series. Their taxonomy is complicated by hybridization and apomixis. Further studies could help elucidate relationships between and within species. While preparing an account of Cotoneaster for the Flora of China, volume 9 (Lu \& Brach, in press), the present authors noted that the following new combinations are necessary.

Cotoneaster glaucophyllus Franchet (1890: 222) is a semi-evergreen shrub endemic to southwestern China (Guangxi, Guizhou, Sichuan, and Yunnan Provinces), with elliptic to ovate, glaucous leaves, compact, compound, to more than 50-flowered corymbs, spreading, white petals, and reddish yellow, ovoid to obovoid fruit.

In addition to its typical variety, two other named varieties occur in China: Cotoneaster glaucophyllus var. vestitus W. W. Smith (1917: 21) and variety meiophyllus W. W. Smith (loc. cit.). A form of this species, f. serotinus (Hutchinson) Stapf, which was originally described at specific rank (C. serotinus
Hutchinson), is best treated as a fourth variety; thus a new combination is required.

Cotoneaster glaucophyllus Franchet var. serotinus (Hutchinson) L. T. Lu \& A. R. Brach, comb. nov. Basionym: Cotoneaster serotinus Hutchinson, Bot. Mag. 146: t. 8854. 1920. Cotoneaster glaucophyllus Franchet f. serotinus (Hutchinson) Stapf, Bot. Mag. 153: t. 9171. 1929. TYPE: plant cultivated in the garden of Mr. G. H. Wollaston, Flaxley Cottage, Flax Bourton, United Kingdom, 1919 (fr), grown from seeds collected in China. Yunnan: $G$. Forrest 6754 (holotype, K).

This fourth variety occurs from 1900 to $3000 \mathrm{~m}$ in mountainous regions of western Yunnan Province. It is characterized by having leaf blades 4-6 $\mathrm{cm}$, abaxially pubescent when young, gradually glabrescent, and inflorescences 50- to 60-flowered, white tomentose initially, later glabrescent. The four varieties of Cotoneaster glaucophyllus are distinguished as follows:

\section{Key to Varieties of Cotoneaster glaUcophyllus}

la. Leaf blade $3.5-6 \mathrm{~cm}$.

2a. Inflorescences to 40-flowered, with soft yellow hairs . . . . . . . var. glaucophyllus

2b. Inflorescences 50- to 60-flowered, white tomentose initially, later glabrescent .... $\ldots \ldots \ldots \ldots \ldots \ldots$ var. serotinus

1b. Leaf blade $1.5-3 \mathrm{~cm}$.

3a. Leaf blade abaxially densely yellow tomentose when young, later glabrescent; inflorescences to 40-flowered, larger, densely white tomentose when young ........ var. vestitus

3b. Leaf blade abaxially slightly pubescent or subglabrous; inflorescences 6- to 12 -flowered, smaller, with soft hairs .. var. meiophyllus

Cotoneaster bullatus Bois (in Vilmorin \& Bois, 1904: 119) is a deciduous shrub endemic to southwestern China (Hubei, Sichuan, Xizang, and Yunnan Provinces), with conspicuously rugose, bullate

Novon 12: 495-496. 2002. 
leaves, lax, 5- to 31-flowered corymbs, erect, pink petals, and red to dark purple, globose or obovoid fruit. In addition to its typical variety, another named variety occurs in China: C. bullatus var. macrophyllus Rehder \& E. H. Wilson (in Sargent, 1912: 164). A form of this species, f. floribundus (Stapf) Rehder \& E. H. Wilson (originally described as a form of $C$. moupinensis Franchet), is best treated as a third variety of $C$. bullatus; thus a new combination is required.

Cotoneaster bullatus Bois var. floribundus (Stapf) L. T. Lu \& A. R. Brach, comb. nov. Basionym: Cotoneaster moupinensis Franchet $\mathrm{f}$. floribundus Stapf, Bot. Mag. 135: t. 8284. 1909. Cotoneaster bullatus f. floribundus (Stapf) Rehder \& E. H. Wilson, in Sargent, Pl. Wilson. 1: 165. 1912. TYPE: plant cultivated at the Royal Botanic Gardens, Kew, United Kingdom, from seed collected in China. Sichuan: "near Tachienlu" [Kangding], M. Vilmorin 2123 (holotype, K).

This second variety occurs in mountain forests from 900 to $2100 \mathrm{~m}$ in western Sichuan Province. It is characterized by having petioles $1.5(-2.5) \mathrm{mm}$, leaf blades ovate or obovate, less than $5 \mathrm{~cm}$, and inflorescences 4-6 cm in diameter, 15- to 31-flowered.

The three varieties of Cotoneaster bullatus are distinguished as follows:

\section{Key to Varieties of Cotoneaster bULLATUS}

la. Petiole 3-6 mm; inflorescences 5- to 13-flowered ................ var. bullatus

1b. Petiole 1.5-2.5 $\mathrm{mm}$; inflorescences 11 - to 31 flowered.

2a. Leaf blade $5-15 \times 2.5-8 \mathrm{~cm}$, petiole ca. 2 $\mathrm{mm}$; inflorescences 5-8 cm diam., 11- or more flowered . . . . . . var. macrophyllus

2b. Leaf blade usually less than $5 \mathrm{~cm}$, petiole usually less than $2 \mathrm{~mm}$; inflorescences 4-6 cm diam., 15- or more flowered . . . . .

$\ldots \ldots \ldots \ldots$ var. floribundus

Cotoneaster gracilis Rehder \& E. H. Wilson (in Sargent, 1912: 167) is a deciduous shrub endemic to central China (Gansu, Hubei, Shaanxi, and Sichuan Provinces), with ovate to broadly elliptic leaves, lax, 1- to 7-flowered corymbs, erect, red petals and red, obovoid, puberulous fruit. In addition to its typical variety, another species, Cotoneaster difficilis G. Klotz, is very similar to it, but differs mainly by its smaller leaf blades and fewflowered inflorescences. This latter species is best treated at varietal rank under $C$. gracilis; thus a new combination is required.

Cotoneaster gracilis Rehder \& E. H. Wilson var. difficilis (G. Klotz) L. T. Lu, comb. nov. Basionym: Cotoneaster difficilis G. Klotz, Wiss. Z. Friedrich-Schiller-Univ. Jena, Math.-Naturwiss. Reihe 21(5-6): 1017. 1972. TYPE: China. Sichuan: "valley of Hsao chin ho [Xiaojin River] near Mon kong ting, 7-10.000 ft.," June 1908, E. H. Wilson 2169 (holotype, A; isotype, $\mathrm{BM})$.

This variety occurs from 1800 to $3000 \mathrm{~m}$ in mountain regions of southeastern Gansu and western Sichuan Provinces. Cotoneaster gracilis var. difficilis is characterized by having leaf blades ovateelliptic to broadly elliptic, 7-14 × 5.5-8 mm, abaxially tomentose initially, and inflorescences 1to 3(to 6)-flowered. It is distinguished from the typical variety as follows:

\section{Key to Varieties of Cotoneaster GRaCiLIS}

la. Leaf blade ovate to oblong-ovate, 20-35 × 10$20 \mathrm{~mm}$, densely tomentose abaxially; inflorescences 3- to 7 -flowered . . . . . . . var. gracilis

1b. Leaf blade ovate-elliptic to broadly elliptic, 7$14 \times 5.5-8 \mathrm{~mm}$, initially tomentose abaxially; inflorescences 1- to 3(to 6)-flowered . . var. difficilis

Acknowledgments. We thank Nicholas J. Turland (MO) for nomenclatural advice and editorial help. We are grateful to two anonymous reviewers for their comments.

\section{Literature Cited}

Franchet, A. 1889-1890. Plantae delavayanae. Plantes de Chine recueillis au Yun-nan par l'Abbé Delavay et décrites par A. Franchet. Paul Klincksieck, Paris.

Lu, Lingdi [Ling-ti] \& Brach, A. R. In press. Cotoneaster Medikus. In: Zhengyi Wu \& P. H. Raven (editors), Flora of China, Vol. 9. Science Press, Beijing, and Missouri Botanical Garden Press, St. Louis.

Sargent, C. (editor). 1911-1917. Plantae Wilsonianae. An Enumeration of the Woody Plants Collected in Western China for the Arnold Arboretum of Harvard University During the Years 1907, 1908, and 1910 by E. H. Wilson. Harvard Univ. Press, Cambridge, Massachusetts.

Smith, W. W. 1917. Diagnoses specierum novarum in herbario Horti Regii Botanici Edinburgensis cognitarum (species asiaticae). Notes Roy. Bot. Gard. Edinburgh 10: 1-78.

Vilmorin, M. de \& D. G. J. M. Bois. 1904. Fruticetum Vilmorinianum. Catalogus primarius. Catalogue des arbustes existant en 1904 dans la collection de M. Maurice Levèque de Vilmorin avec la description d'espèces nouvelles et d'introduction récente. Librairie Agricole, Paris. 